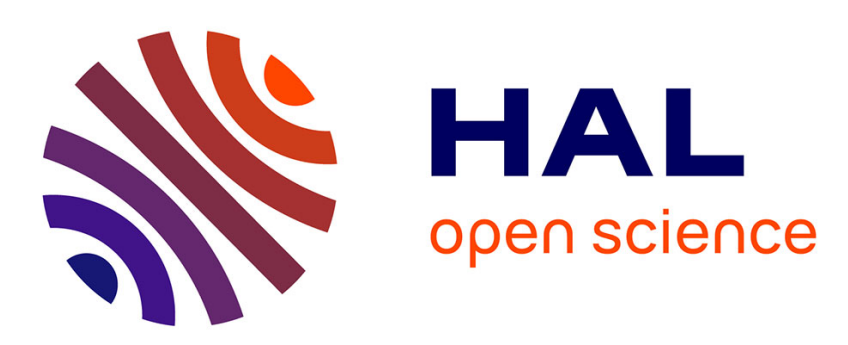

\title{
A standardised protocol for measuring phenoloxidase and prophenoloxidase in the honey bee, Apis mellifera
}

Alice Laughton, Michael Siva-Jothy

\section{To cite this version:}

Alice Laughton, Michael Siva-Jothy. A standardised protocol for measuring phenoloxidase and prophenoloxidase in the honey bee, Apis mellifera. Apidologie, 2011, 42 (2), pp.140-149. 10.1051/apido/2010046. hal-01003580

\section{HAL Id: hal-01003580 \\ https://hal.science/hal-01003580}

Submitted on 1 Jan 2011

HAL is a multi-disciplinary open access archive for the deposit and dissemination of scientific research documents, whether they are published or not. The documents may come from teaching and research institutions in France or abroad, or from public or private research centers.
L'archive ouverte pluridisciplinaire HAL, est destinée au dépôt et à la diffusion de documents scientifiques de niveau recherche, publiés ou non, émanant des établissements d'enseignement et de recherche français ou étrangers, des laboratoires publics ou privés. 


\title{
A standardised protocol for measuring phenoloxidase and prophenoloxidase in the honey bee, Apis mellifera*
}

\author{
Alice M. LAUGHTON ${ }^{1,2}$, Michael T. SIVA-JOTHY ${ }^{1}$ \\ ${ }^{1}$ Department of Animal and Plant Sciences, University of Sheffield. Western Bank, Sheffield, S10 2TN, UK \\ ${ }^{2}$ Biology Department, Emory University, O. Wayne Rollins Research Center, 1510 Clifton Road NE, Atlanta, \\ GA, 30322, USA
}

Received 21 September 2009 - Revised 17 February 2010 - Accepted 17 February 2010

\begin{abstract}
The prophenoloxidase activating system (ProPO-AS) is an integral part of the constitutive innate immune response in insects, the products of which are commonly assayed to assess an individual's ability to respond to immune challenges. However, there is considerable variation in the methodologies associated with these assays, and as such, it is not always clear how to interpret results. We have optimised assays for measuring phenoloxidase in its active (PO) and zymogen (ProPO) forms in the honey bee, Apis mellifera. Contrary to results for other insects, we found that the activator $\alpha$-chymotrypsin, when used at a low concentration $\left(0.5 \mathrm{mg} \mathrm{mL}^{-1}\right)$, combined with a minimal activation time $(5 \mathrm{~min})$, provided optimal conditions for assaying ProPO. In addition, a saturated L-dopa solution was required for assaying both PO and ProPO. The results highlight the importance of defining the working parameters of each assay to be species-specific.
\end{abstract}

\section{honey bee / Apis mellifera / phenoloxidase / innate immunity / activator}

\section{INTRODUCTION}

The innate immune system of insects consists of two broad categories of effectors: constitutive and induced (Schmid-Hempel, 2005). Constitutive responses generally comprise the humoral prophenoloxidase activating system (ProPO-AS) and cellular responses including coagulation, phagocytosis, nodule formation and encapsulation (Gillespie et al., 1997). Whilst not maintained at a constant maximum, constitutive immune responses are always present (Siva-Jothy et al., 2005; Cerenius et al., 2008), are non-specific but immediate in effect, and are responsible for clearing most of a microbial challenge very rapidly after infection (Haine et al., 2008). By contrast the induced responses, such as antimicrobial pep-

Corresponding author: A.M. Laughton, alice.laughton@emory.edu

* Manuscript editor: Bernd Grünewald tides, occur only once the invading pathogen has been recognised. They are specific and take longer to produce, but are longer lasting in their effect (Boman and Hultmark, 1987).

We concentrate on one important arm of the constitutive immune responses. The ProPOAS is a series of complex interactions between enzymes and their zymogens, leading to the production the enzyme phenoloxidase (PO; monophenol, L-dopa:oxygen oxidoreductase, EC 1.14.18.1). PO activity ultimately results in the formation of melanin, which is subsequently involved in cuticle sclerotisation, wound healing and cellular defence responses (Mason, 1955; Ratcliffe et al., 1984; Cerenius et al., 2008). Due to the cytotoxic nature of the by-products of this process, $\mathrm{PO}$ is commonly stored as its inactive precursor prophenoloxidase (ProPO), and activated as part of the cascade following the recognition of foreign compounds (Ratcliffe et al., 1984; Riley, 1988; Gillespie et al., 1997; Söderhäll and 
Cerenius, 1998). Consequently, two different measurements of PO may be taken when assaying insect immunity: the freestanding "naturally active" PO (henceforth referred to as PO activity), and the total "potential" $\mathrm{PO}$ response (ProPO activity), measured after the artificial activation of the precursor ProPO.

ProPO is naturally activated by bacterial and fungal cell wall components (Ratcliffe et al., 1984; Söderhäll and Cerenius, 1998). Commonly, laminarin, lipopolysaccharides (LPS) and $\alpha$-chymotrypsin are used as artificial ProPO activators, but have varying levels of success in different insects (Brookman et al., 1989; Thompson, 2002; Korner and Schmid-Hempel, 2004; Eleftherianos et al., 2006). Laminarin (a storage polysaccharide of brown algae, made up of 1,3-glucans) activates ProPO in the mealworm beetle, Tenebrio molitor, and induces nodule formation in the African migratory locust, Locusta migratoria (Thompson, 2002; Mullen and Goldsworthy, 2006). LPS (a non-pathogenic cell wall component derived from Escherichia coli) has been shown to induce nodule formation when injected into the desert locust, Schistocerca gregaria (Gunnarsson and Lackie, 1985), and increased phagocytosis in the wax moth, Galleria melonella (Ratcliffe et al., 1984). Chymotrypsin is a protease that hydrolyses the peptide bonds in ProPO to produce active PO, and activates ProPO in many insects (e.g. Saul and Sugumaran, 1988; Kopacek et al., 1995). All of these compounds therefore have the potential for assaying ProPO activity action in honey bees.

Whilst the honey bee, Apis mellifera L., is of great economical value, it is subject to a wide range of micro- and macro-parasites including viruses, bacteria, fungi and mites (Bailey and Ball, 1991; Allen and Ball, 1996; Carreck and Williams, 1998). The immune responses raised against these pathogens are costly and impact on other life-history traits (e.g. Bailey and Ball, 1991; Evans and Pettis, 2005). With the role that immunity plays in honey bee health recently coming under scrutiny due to the phenomenon termed Colony Collapse Disorder (Oldroyd, 2007; Cox-Foster et al., 2007), developing an accurate, reliable and cost-effective assay of immune function in honey bees is vital. Quantification of PO/ProPO activity offers the potential for assaying 'health', as increased activity correlates with higher levels of pathogen resistance in several study systems (Tenebrio molitor (Barnes and SivaJothy, 2000; Armitage and Siva-Jothy, 2005), Drosophila (Braun et al., 1998), Glossina sp. (Nigam et al., 1997) and Manduca sexta (Eleftherianos et al., 2006)). Levels of PO activity are typically assayed through its catalytic conversion of L-dopa (3,4-dihydroxyL-phenylalanine, colourless) to dopachrome (red-brown colour), which is measured photometrically (Horowitz and Shen, 1952; Barnes and Siva-Jothy, 2000; Thompson, 2002). In the present study, we define the optimum assay parameters for PO and ProPO activity, including a review of ProPO activators, in order to measure this key immune enzyme in the honey bee.

\section{MATERIALS AND METHODS}

\subsection{Bees}

Adult honey bee workers were collected from a single colony of healthy British hybrid bees (Apis mellifera L.) maintained at the University of Sheffield. Brood frames were incubated overnight $\left(36 \pm 1{ }^{\circ} \mathrm{C}, 24 \mathrm{~h}\right.$ dark photoperiod, $40 \pm 2 \% \mathrm{hu}-$ midity) and newly emerged adults collected the following morning. Bees were maintained in cages $\left(36 \pm 1{ }^{\circ} \mathrm{C}, 12: 12 \mathrm{~h} \mathrm{~L}: \mathrm{D}\right.$ photoperiod, $50 \%$ sucrose solution ad libitum) for $24 \mathrm{~h}$ prior to sampling as previous experiments found $24 \mathrm{~h}$ to be the minimum age at which to successfully assay PO/ProPO activity (data not shown). Bees collected were therefore between 24 and $36 \mathrm{~h}$ old.

\subsection{Evaluating Km}

To obtain the maximum linear rate of colour change of L-dopa to dopachrome, and consequently an accurate measure of the concentration of $\mathrm{PO}$ associated with a reaction, all aspects of the reaction mixture must be optimised. The enzyme kinetics can be calculated using methods set out in Henderson (1992) and extrapolating data to find the constants of the reaction. Honey bee haemolymph 
was found to conform to the Michaelis-Menten equation (unpubl. data), with a Michaelis constant $(\mathrm{Km})$ of $5.75 \mathrm{mM}$, giving an optimal reaction velocity (Vmax, equal to $2 \times \mathrm{Km}$ ) with $11.5 \mathrm{mM} \mathrm{L}$-dopa (data not shown). Although solubilities as high as 10 or $20 \mathrm{mM}$ have been recorded (Sinsabaugh et al., 1991; Bidla et al., 2009), L-dopa is considered sparingly soluble in water, making the Vmax calculated for honey bees unlikely to be easily achievable (Merck Index, 2006). To establish a workable concentration of L-dopa to yield maximum possible results, L-dopa solutions were tested using the $\mathrm{Km}$ (5.75 mM; after $10 \mathrm{~min}$ vortexing the solution reached saturation at this point and failed to dissolve further to provide the concentration needed for $2 \mathrm{~km}$ $\left.\left(\mathrm{V}_{\max }\right)\right)$ and half $\mathrm{Km}(2.88 \mathrm{mM})$ concentrations in distilled water. The saturated solution was filtered and recorded with a final concentration of between half $\mathrm{Km}$ and $\mathrm{Km}(2.88-5.75 \mathrm{mM})$.

Haemolymph extracts were collected and pooled from perfusion bleeds of 10 workers. In a standardised method for this and all subsequent collections, perfusion bleeds were carried out using $0.5 \mathrm{~mL}$ ice-cold sodium cacodylate buffer (NaCac; $0.001 \mathrm{M}$ sodium cacodylate, $0.005 \mathrm{M}$ calcium chloride, $\mathrm{pH}$ 6.5). Samples were immediately frozen $\left(-90^{\circ} \mathrm{C}\right)$ to disrupt the haemocytes. Prior to use, samples were defrosted on ice, vortexed briefly to ensure thorough mixing, and centrifuged to remove cell debris $\left(4{ }^{\circ} \mathrm{C}, 80000 \mathrm{G}, 15 \mathrm{~min}\right)$. To ensure that PO was not a limiting factor in the assay, aliquots of the pooled haemolymph were tested at five different dilution levels $(1,1 / 2,1 / 4$, $1 / 8,1 / 16$ ) for both L-dopa concentrations. Each Ldopa:haemolymph dilution level combination was repeated seven times. As standard for this and all subsequent $\mathrm{PO}$ activity assays, $20 \mu \mathrm{L}$ aliquots of the haemolymph sample were mixed with $140 \mu \mathrm{L}$ $\mathrm{dH}_{2} \mathrm{O}$ and $20 \mu \mathrm{L}$ PBS (phosphate buffered solution; $150 \mathrm{mM} \mathrm{NaCl}, 10 \mathrm{mM} \mathrm{Na} 2 \mathrm{HPO}_{4}, \mathrm{pH} 6.5$ ) in a pre-chilled 96-well plate (chilled plates prevent the reaction starting before required). Lastly, $20 \mu \mathrm{L} \mathrm{L}$-dopa was added, and the reaction allowed to proceed at $30{ }^{\circ} \mathrm{C}$ in a spectrophotometer (VersaMax tunable microplate reader, Molecular Devices). Readings were taken at $490 \mathrm{~nm}$ every $15 \mathrm{~s}$ for $1 \mathrm{~h}$ and analysed using Softmax Pro v5.0.1 software. Enzyme activity $\left(\mathrm{V}_{\max }\right)$ was measured as the maximum linear rate of substrate conversion. Typically a lag period of $200 \mathrm{~s}$ was recorded whilst plates reached optimal reaction temperature and substrates were mixed. Following this, the linear recording period was on average taken over the subsequent $1200 \mathrm{~s}$ (after this time, samples may start to plateau, depending on treatment and assay type (PO/ProPO activity)).

The experiment was repeated to test the ProPO activity assay: the assay was identical to that for PO activity, but $5 \mu \mathrm{L}$ of the $\mathrm{dH}_{2} \mathrm{O}$ in the reaction mixture was replaced with $5 \mu \mathrm{L} \alpha$-chymotrypsin (5 mg mL ${ }^{-1}$ ), a common ProPO activator. The reaction mixture was incubated at room temperature $\left(19 \pm 2{ }^{\circ} \mathrm{C}\right)$ for $5 \mathrm{~min}$ to allow activation to occur, with gentle agitation of the plate to allow complete mixing of reaction components, before the L-dopa was added and recording started. ProPO activity was quantified as the maximum linear rate of the reaction. This protocol for used for all subsequent assays of ProPO activity.

\subsection{ProPO activators}

Commonly, laminarin, LPS and $\alpha$-chymotrypsin are used as artificial ProPO activators, but all have exhibited varying degrees of success in different study systems (Brookman et al., 1989; Thompson, 2002; Korner and Schmid-Hempel, 2004; Frassens et al., 2008). To assess which activator works best for honey bees, 12 workers were perfuse bled as standard (samples were used individually, not pooled). Four $20 \mu \mathrm{L}$ aliquots of each sample were used for the standard ProPO activity assay (see above). Each aliquot received $5 \mu \mathrm{L}$ of the different ProPO activators (concentrations determined following Thompson, 2002): either laminarin $\left(1 \mathrm{mg} \mathrm{mL} L^{-1}\right)$, LPS $\left(0.5 \mathrm{mg} \mathrm{mL}^{-1}\right), \alpha-$ chymotrypsin $\left(5 \mathrm{mg} \mathrm{mL}^{-1}\right)$, or a control $\left(\mathrm{dH}_{2} \mathrm{O}\right)$. Following incubation, $20 \mu \mathrm{L} \mathrm{L}$-dopa at a saturated concentration was added to the wells and the ProPO activity recorded as standard.

\subsection{Activator timecourse}

The length of time that samples are incubated, both with or without a ProPO activator, prior to assaying differs between studies (Thompson, 2002; Eleftherianos et al., 2006; Schmid et al., 2008; Wilson-Rich et al., 2008). Preliminary experiments showed that PO rapidly breaks down on defrosting, even if stored on ice (unpubl. data). In addition, using a non-specific protease with no regulatory mechanism, such as $\alpha$-chymotrypsin, as a ProPO activator carries the risk of hydrolysis continuing unchecked, and subsequently recording inaccurate levels of PO activity. Both of these factors highlight 
the importance of minimising the incubation time of samples. To determine the incubation time needed to activate ProPO in honey bees, 48 workers were perfuse bled. Prior to use, samples were pooled and incubated on ice for the duration of the experiment. Using the same four ProPO activators as above, their effectiveness was tested against aliquots of the pooled sample over different incubation times. Samples were incubated with each activator for 5 , 10,20 or $30 \mathrm{~min}$ at room temperature $\left(19 \pm 2{ }^{\circ} \mathrm{C}\right)$ before adding L-dopa and allowing the assay to proceed as standard. Each time period:activator combination was repeated five times.

\subsection{Activator concentration}

To minimise any damage caused by the $\alpha$ chymotrypsin when added to a haemolymph sample (Muhlia-Almazán et al., 2008), its concentration was evaluated to find the lowest workable concentration needed to ensure maximum ProPO activation. Perfusion-bled haemolymph was pooled from 10 workers and $20 \mu \mathrm{L}$ aliquots used in the standard ProPO activity protocol. $\alpha$-chymotrypsin was tested at six concentrations: $0.25 \mathrm{mg} \mathrm{mL}^{-1}, 0.5 \mathrm{mg} \mathrm{mL}^{-1}$, $1.0 \mathrm{mg} \mathrm{mL}^{-1}, 2.0 \mathrm{mg} \mathrm{mL}^{-1}, 5.0 \mathrm{mg} \mathrm{mL}^{-1}$ and $10.0 \mathrm{mg} \mathrm{mL}^{-1}$, with each $\alpha$-chymotrypsin concentration repeated five times.

\section{RESULTS}

\subsection{Evaluating Km}

\subsubsection{PO activity}

There was a significant effect of L-dopa concentration on the $\mathrm{V}_{\max }$ (rate of change in optical density) of PO activity, with the saturated $\mathrm{Km}$ concentration recording a higher enzyme activity level than the half Km L-dopa concentration (Fig. 1, $\mathrm{F}_{1,47}=9.35, P<$ 0.01 , data $\log 10$ transformed). The difference between the two L-dopa concentrations was amplified as the concentration of PO in the sample became increasingly limited. Despite samples being pooled, we saw some variation between repeats at the lower sample concentrations. This was likely due to the fact that the low levels of PO present in the samples produced more error in the reaction curves due to the limited sensitivity of the recording apparatus.

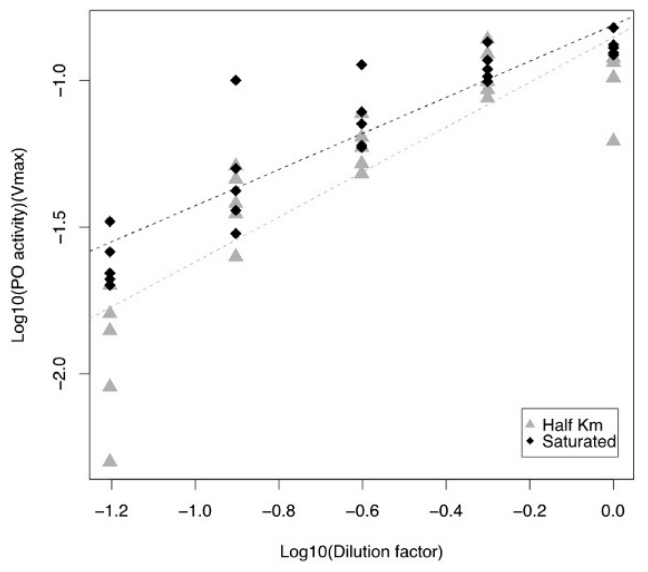

Figure 1. Dilution series showing the level of PO activity $\left(\mathrm{V}_{\max }\right)$ in haemolymph samples of worker bee ( $24 \mathrm{~h}$ old) assayed with two different Ldopa concentrations. A saturated L-dopa solution recorded higher enzyme activity levels than the half Km L-dopa concentration $\left(\mathrm{F}_{1,47}=9.35, P<0.01\right.$, data $\log 10$ transformed).

\subsubsection{ProPO activity}

There was a significant interaction of Ldopa concentration with the sample dilution factor (Fig. 2, $\mathrm{F}_{1,46}=10.19, P<0.01$, data $\log 10$ transformed). In the undiluted haemolymph sample, the saturated L-dopa solution recorded a higher level of ProPO activity $\left(\mathrm{V}_{\max }\right)$ than the half $\mathrm{Km}$ L-dopa solution.

\subsection{ProPO activators}

There was a significant difference between the effectiveness of the ProPO activators on honey bee haemolymph (Fig. 3, $\mathrm{F}_{3,40}=46.5$, $P<0.001$, data $\log 10$ transformed), with considerably more ProPO activated by $\alpha$ chymotrypsin than any of the other activators.

\subsubsection{Activator timecourse}

There was a significant interaction between activator and incubation time on the levels of ProPO activity recorded (Fig. 4, $\mathrm{F}_{3,72}=$ 4.03, $P=0.01$, data $\log 10$ transformed). Across all activator groups the amount of 


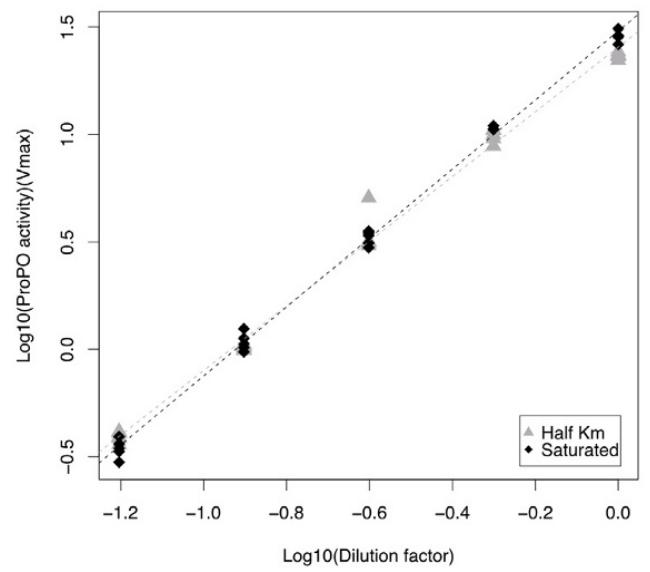

Figure 2. Dilution series showing the level of ProPO activity $\left(\mathrm{V}_{\max }\right)$ in haemolymph samples of worker bee ( $24 \mathrm{~h}$ old) assayed with two different L-dopa concentrations. There was a significant interaction of L-dopa with the sample dilution factor $\left(\mathrm{F}_{1,46}=10.19, P<0.01\right.$, data $\log 10$ transformed $)$.

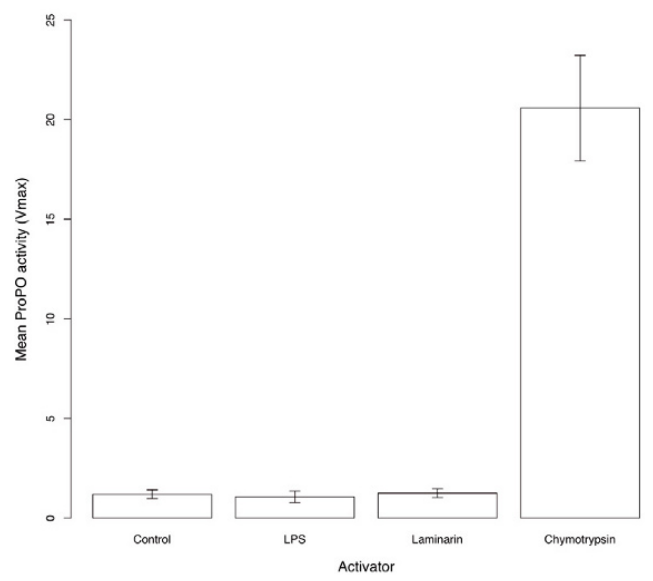

Figure 3. Effect of different ProPO activators on the mean $( \pm 1$ s.e. $)$ ProPO activity recorded $\left(\mathrm{V}_{\max }\right)$ $\left(\mathrm{F}_{3,40}=46.5, P<0.001\right)$.

ProPO activity $\left(\mathrm{V}_{\max }\right)$ assayed significantly decreased with increasing incubation time. As before, $\alpha$-chymotrypsin activated vastly more ProPO than the other activators. Consequently, a minimum activation time should be used to conserve maximum ProPO activity for assaying, whilst allowing time for reaction components to be thoroughly mixed and the protease

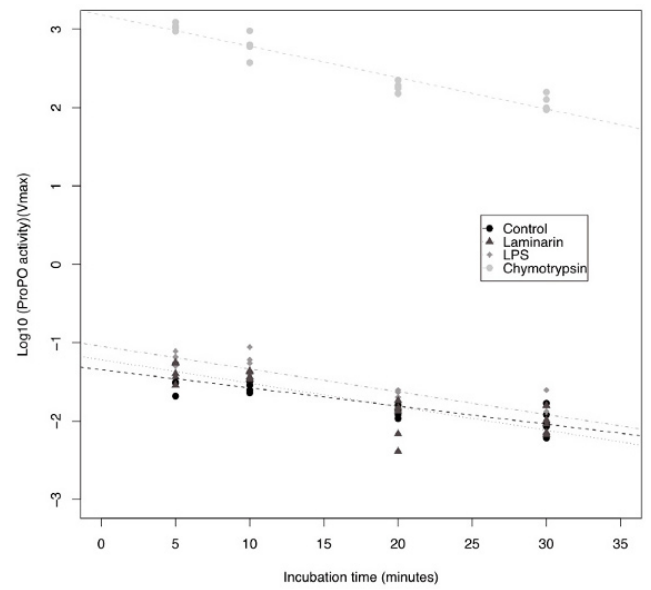

Figure 4. ProPO activator timecourse showing the ProPO activity $\left(\mathrm{V}_{\max }\right)$ recorded from three different activators (laminarin, LPS and $\alpha$-chymotrypsin) and a control $\left(\mathrm{dH}_{2} \mathrm{O}\right)$ following incubation periods of 5, 10, 20 and 30 min with the haemolymph sample prior to the addition of L-dopa and subsequent assay reading. There was a significant interaction between activator and incubation time $\left(\mathrm{F}_{3,72}=4.03\right.$, $P=0.01$, data $\log 10$ transformed).

brought up to working temperature before starting the assay recording.

\subsubsection{Activator concentration}

Regression analysis showed a significant effect of $\alpha$-chymotrypsin concentration on ProPO activity (Fig. 5, $\mathrm{F}_{1,28}=19.16, P<$ $\left.0.001, \mathrm{r}^{2}=0.406\right)$. The use of higher concentrations of $\alpha$-chymotrypsin resulted in lower levels of ProPO activity. As $\alpha$-chymotrypsin is potentially destructive, it is preferable to use the lowest concentration available that still yields maximum results. Consequently the lowest concentration should be taken from the three concentrations that showed higher levels of ProPO activation (points above the regression line), giving an optimal $\alpha$-chymotrypsin concentration of $0.5 \mathrm{mg} \mathrm{mL}^{-1}$.

\subsection{Optimal reaction conditions}

Following these results, a saturated L-dopa solution (concentration between $2.88 \mathrm{mM}$ 


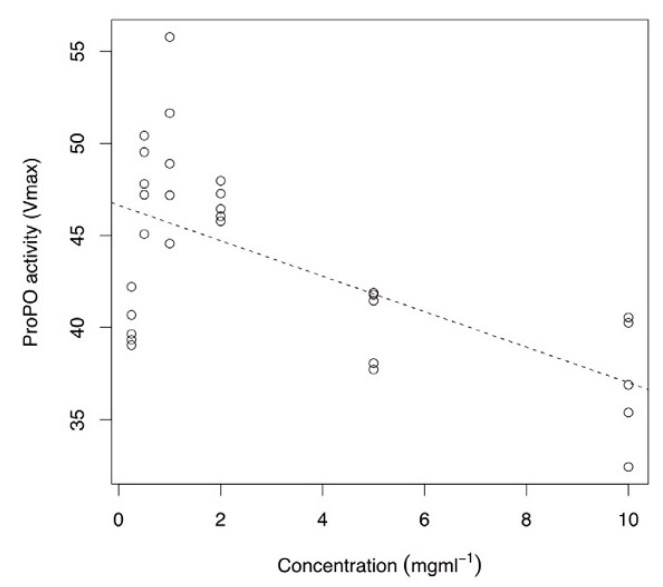

Figure 5. Effect of $\alpha$-chymotrypsin concentration $\left(\mathrm{mg} \mathrm{mL}^{-1}\right)$ on ProPO activity $\left(\mathrm{V}_{\max }\right)\left(\mathrm{F}_{1,28}=19.16\right.$, $\left.P<0.001, \mathrm{r}^{2}=0.406\right)$.

and $5.75 \mathrm{mM}$ ) should be used for the optimal assaying of PO and ProPO activity in honey bees. For the activation of ProPO, samples should be incubated with $\alpha$-chymotrypsin $\left(0.5 \mathrm{mg} \mathrm{mL}^{-1}\right)$ for 5 minutes at room temperature $\left(19 \pm 2{ }^{\circ} \mathrm{C}\right)$ prior to the addition of L-dopa.

\section{DISCUSSION}

This study has defined standard working parameters for measuring honey bee PO and ProPO activity. It is important that assays of this enzyme are standardised given the variation in this effector system between individual bees (Laughton, 2008). These methods have subsequently been successfully used to assay PO and ProPO activity levels in both workers and drones, over all ontogenetic stages, and with varying levels of parasitic infection (Laughton, 2008), and we believe, will be equally applicable to other honey bee subspecies.

A saturated L-dopa solution with a concentration between 2.88 and $5.75 \mathrm{mM}$ (5.67$11.34 \mathrm{mg} \mathrm{mL}^{-1}$ ) provided a conservative estimate of enzymic activity, and should be preferentially used in future experiments. This concentration is in the same magnitude as that previously calculated via the same methods for use in a PO activity assay of Tenebrio molitor (optimal found to be $4 \mathrm{mg} \mathrm{mL}^{-1}$, Moret and Siva-Jothy, 2003), and used in assays of bumble bees (Korner and Schmid-Hempel, 2004) and honey bees (Schmid et al., 2008). It is not known why we were unable to produce the concentrations of $10 \mathrm{mM}$ reported in Sinsabaugh et al. (1991), although it is possible that heating may have aided dissolution in this case.

The use of $\alpha$-chymotrypsin as the most successful activator of ProPO in honey bees contrasts with the results for $T$. molitor (Thompson, 2002), but is supported by similar findings in Schistorcerca gregaria (Franssens et al., 2008). $\alpha$-chymotrypsin is a general protease and as such is capable of causing damage if not controlled (Muhlia-Almazán et al., 2008). Higher levels of $\alpha$-chymotrypsin had a negative effect on ProPO activity, highlighting the sensitivity of the assay to changes in activator concentration. Further research into the effects of ProPO activators confirmed that long incubation times with an activator can dramatically reduce the concentration of PO available for assay. Consequently a minimal incubation period of five minutes should be used when assaying ProPO activity in honey bees. ProPO will breakdown into $\mathrm{PO}$ naturally over time (the addition of a ProPO activator speeds this process to completion). Longer incubations, as used in previous studies (e.g. Eleftherianos et al., 2006; Schmid et al., 2008), allows time for excess activated PO (from ProPO) to be degraded by the ProPO-activating enzyme within the haemolymph sample, or removed by combining into larger protein aggregates, both regulatory mechanisms employed in vivo to avoid the deleterious autoimmune effects of high concentrations of active PO (Nappi et al., 1995, 2004; K. Söderhäll, pers. commun.). Although samples assayed using longer incubation periods will be comparable to each other, they reflect neither a measure of the maximum immune investment (i.e. all ProPO and all PO activity), nor the singular PO activity response. It has been shown that some ProPO is spontaneously activated during the process of haemolymph extraction (Bidla et al., 2009), and it may be this by-product that is being measured in the PO activity assay. Whilst we 
cannot rule out the fact that such activation has occurred, we would expect these measures to be uniform across all individuals studied when subject to the same collection protocols. Nevertheless, we have recorded variation in measures of PO activity correlating with differences in season and treatment (Laughton, 2008), which suggests that although a baseline activation may exist corresponding to the collection method, PO activity is still a valid measure when comparing like for like. However, it may be prudent to refer to such a measure as "naturally activated" rather than "constitutive" PO activity.

The ratio of PO to ProPO activity in bees was found to be approximately 1 to 365 in these experiments, much greater than that recently seen in the amphipod Gammarus pulex (activity levels of ProPO found to be approximately 15 times greater than those of PO, Cornet et al., 2009a). However, in preliminary data for this study, and subsequent experiments, PO activity was found to be the more variable parameter compared to ProPO activity; the high variation in honey bee $\mathrm{PO}$ activity levels associated with seasonal and treatment effects could cause the ratio of $\mathrm{PO}$ to ProPO activity to drop as low as 1 in 50 in some cases (Laughton, 2008). This difference in plasticity between the two measures was also found in G. pulex (Cornet et al., 2009b), and may represent the transient nature of active PO in the haemolymph, and the variation in the relative costs of maintaining the two immune responses. Consequently, the choice of assay within a study should be carefully considered to reflect the questions being asked.

Phenoloxidase undoubtedly plays many crucial roles in the organisation and efficacy of the innate immune system of insects, and it has long been used to measure an individual's immune defence ability (Brookman et al., 1989; Söderhäll and Cerenius, 1998; Wilson et al., 2001; Sugumaran, 2002). Nevertheless, contradictory evidence exists that increasing PO concentrations are indeed correlated with an increased resistance to pathogens, and the use of PO activity assays as a good measure of the immune response of an individual is not without controversy (Adamo, 2004; Mucklow et al., 2004; Cerenius et al., 2008). Whilst some studies have shown no correlation between PO concentration and pathogen susceptibility (Adamo, 2004; Mucklow et al., 2004; Leclerc et al., 2006; Schwarzenbach and Ward, 2007), others provide compelling evidence to suggest otherwise (Nigam et al., 1997; Braun et al., 1998; Barnes and Siva-Jothy, 2000; Brown et al., 2003; Armitage and Siva-Jothy, 2005; Cerenius et al., 2008; Eleftherianos et al., 2008). Subsequent studies infecting bees with bacterial derivatives found a negative effect of immune challenge on PO and ProPO activity, suggesting that phenoloxidase does play an important role in the immune response in honey bees (Laughton, 2008). However, to build up a fuller picture, further studies utilising multiple natural bee parasites should be carried out, as host phenoloxidase immune responses may be parasite-specific (Adamo, 2004).

Although the repeatability and consistent measurement of phenoloxidase is particularly important to gain an understanding of the immune system, such assays should ideally be viewed together with other immune parameters. Whilst traditional immunological measures including antimicrobial peptides, fat body mass and haemocyte counts have been successfully applied to immunity studies in the honey bee (e.g. Schmid et al., 2008; Wilson-Rich et al., 2008; Laughton, 2008), recent sequencing of the honey bee genome has revealed candidate immune genes (HGSC, 2006). The characterisation of the cDNA encoding prophenoloxidase has already been found (Lourenço et al., 2005), and together, their assessment using tools such as differential gene expression and quantitative genetics (Evans, 2006) will allow for the comprehensive screening of immune responses to pathogens. These approaches are vital for use in matters of honey bee health, and have recently been employed to distinguish genes with a role in the phenomenon of Colony Collapse Disorder (Johnson et al., 2009). When used in conjunction with the more costeffective traditional assays of immunity they will allow us to better understand the parameters and consequences of the honey bee immune system. 


\section{ACKNOWLEDGEMENTS}

This work was supported by the Natural Environment Research Council. Thanks to Mike Boots for advice during this project.

Un protocole standardisé pour mesurer la phénoloxydase et la prophénoloxydase chez l'abeille, Apis mellifera.

\section{Abeille / Apis mellifera / phénoloxydase / immu- nité innée / activateur}

Zusammenfassung - Ein standardisiertes Protokoll zur Messung der Immunparameter, Phenoloxidase und Prophenoloxidase, bei der Honigbiene Apis mellifera. Honigbienen, Apis mellifera, haben als Bestäuber vieler Nutzpflanzen eine große ökonomische Bedeutung. Allerdings sind sie anfällig für eine ganze Reihe von zum Teil tödlichen $\mathrm{Pa}$ rasiten. Bei der Bekämpfung von Krankheiten kann es uns daher helfen, die Funktionen und die Reaktionen des Immunsystems auf Infektionen besser zu verstehen. Ein integraler Bestandteil des angeborenen Immunsystems ist die Phenoloxidase (PO), die üblicherweise als Vorläufermolekül, Prophenoloxidase (ProPO), gespeichert wird. Die Aktivität dieser beiden Komponenten gilt typischerweise als Maß für die Immunantwort von Insekten. Es gibt jedoch eine große Vielfalt von Methoden, um diese Aktivität zu bestimmen. Unsere Studie zielt darauf ab, ein optimales Protokoll für die Bestimmung der PO und ProPO-Aktivität in der Honigbiene zu entwickeln, welches für zukünftige Forschung angewandt werden kann.

Die Bienenhämolymphe wurde untersucht, indem die Farbänderung durch die Katalyse von L-Dopa zu Dopachrom bestimmt wurde. Die Rate dieser Reaktion entspricht direkt der Aktivität von PO oder ProPO. Im Fall von ProPO muß das Enzym aktiviert werden, bevor es bestimmt werden kann. Die Wirksamkeit von drei verschiedenen ProPOAktivatoren (Lipopolysaccharide, Laminarin und $\alpha$ Chymotrypsin) wurde untersucht. In einem weiteren Experiment zeichneten wir die Dauer der Inkubation auf, die der jeweilige Aktivator benötigte und den Effekt, den dies auf die Aktivierung hatte. Schließlich haben wir die optimale Konzentration des besten ProPO-Aktivators bestimmt.

Eine gesättigte Lösung von L-Dopa war nötig um die PO- und ProPO-Konzentration optimal zu messen. Im Gegensatz zu früheren Untersuchungen fanden wir, da $\beta$ geringe Konzentrationen von $\alpha$ Chymotrypsin $\left(0,5 \mathrm{mg} \mathrm{mL}^{-1}\right)$ nach einer Inkubationsdauer von fünf Minuten vor der Bestimmung die besten Ergebnisse lieferten. Diese Befunde beschreiben die beste Methode, PO und ProPO in der Honigbiene zu messen. Sie zeigen zudem, wie wichtig es ist, die optimalen Assaybedingungen für jede neue Studie zu sichern.

Honigbiene / Apis mellifera / Phenoloxidase / angeborene Immunität / Aktivator

\section{REFERENCES}

Adamo S.A. (2004) How should behavioural ecologists interpret measurements of immunity? Anim. Behav. 68, 1443-1449.

Allen M., Ball B. (1996) The incidence and world distribution of honey bee viruses, Bee World 77, 141162.

Armitage S.A.O., Siva-Jothy M.T. (2005) Immune function responds to selection for cuticular colour in Tenebrio molitor, Heredity 94, 650-656.

Bailey L., Ball B.V. (1991) Honey Bee Pathology, Academic Press Ltd., London.

Barnes A.I., Siva-Jothy M.T. (2000) Densitydependent prophylaxis in the mealworm beetle Tenebrio molitor L. (Coleoptera: Tenebrionidae): cuticular melanization is an indicator of investment in immunity, Proc. R. Soc. Lond. B 267, 177-182.

Bidla G., Hauling T., Dushay M.S., Theopold U. (2009) Activation of insect phenoloxidase after inury: endogenous versus foreign elicitors, J. Innate Imm. 1, 301-308.

Boman H.G., Hultmark D. (1987) Cell-free immunity in insects, Annu. Rev. Microbiol. 41, 103-126.

Braun A., Hoffmann J.A., Meister M. (1998) Analysis of the Drosophila host defense in domino mutant larvae, which are devoid of hemocytes, Proc. Natl. Acad. Sci. USA 95, 14337-14342.

Brookman J.L., Ratcliffe N.A., Rowley A.F. (1989) Studies on the activation of the phenoloxidase system of insects by bacterial cell wall components, Insect Biochem. 19, 47-57.

Brown M.J.F., Moret Y., Schmid-Hempel P. (2003) Activation of host constitutive immune defence by an intestinal trypanosome parasite of bumble bees, Parasitology 126, 253-260.

Carreck N.L., Williams I.H. (1998) The economic value of bees in the UK, Bee World 79, 115-123.

Cerenius L., Lee B.L., Söderhäll K. (2008) The proPOsystem: pros and cons for its role in invertebrate immunity, Trends Immunol. 29, 263-271.

Cornet S., Franceschi N., Bollache L., Rigaud T., Sorci G. (2009a) Variation and covariation in infectivity, virulence and immunodepression in the host-parasite association Gammarus pulexPomphorhynchus laevis, Proc. R. Soc. Lond. B 276, 4229-4236. 
Cornet S., Biard C., Moret Y. (2009b) Variation in immune defence among populations of Gammarus pulex (Crustacea: Amphipoda), Oecologia 159, 257-269.

Cox-Foster D.L., Conlan S., Holmes E.C., Palacios G., Evans J.D., Moran N.A., Quan P., Briese T., Hornig M., Geiser D.M., Martinson V., vanEngelsdorp D., Kalkstein A.L., Drysdale A., Hui J., Zhai J., Cui L., Hutchison S.K., Simons J.F., Egholm M., Pettis J.S., Lipkin W.I. (2007) A metagenomic survey of microbes in honey bee colony collapse disorder, Science 318, 283-287.

Eleftherianos I., Millichap P.J., ffrench-Constant R.H., Reynolds S.E. (2006) RNAi suppression of recognition protein mediated immune responses in the tobacco hornworm Manduca sexta causes increased susceptibility to the insect pathogen Photorhabdus, Dev. Comp. Immunol. 30, 1099_ 1107.

Evans J.D. (2006) Beepath: an ordered quantitativePCR array for exploring honey bee immunity and disease, J. Invertebr. Pathol. 93, 135-139.

Evans J.D., Pettis J.S. (2005) Colony-level impacts of immune responsiveness in honey bees, Apis mellifera, Evolution 59, 2270-2274.

Frassens V., Simonet G., Breugelmans B., Van Soest S., Van Hoef V., Vanden Broeck J. (2008) The role of hemocytes, serine protease inhibitors and pathogen-associated patterns in prophenoloxidase activation in the desert locust, Schistocerca gregaria, Peptides 29, 235-241.

Gillespie J.P., Kanost M.R., Trenczek T. (1997) Biological mediators of insect immunity, Annu. Rev. Entomol. 42, 611-643.

Gunnarsson S.G.S., Lackie A.M.(1985) Hemocytic aggregation in Schistocerca gregaria and Periplaneta americana as a response to injected substances of microbial origin, J. Invertebr. Pathol. 46, 312-319.

Haine E.R., Moret Y., Siva-Jothy M.T., Rolff J. (2008) Antimicrobial defense and persistent infection in insects, Science 322, 1257-1259.

Henderson P.J.F. (1992) Statistical analysis of enzyme kinetic data, in: Eisenthal R., Danson M.J. (Eds.), Enzyme assays: a practical approach, Oxford University Press, Oxford, pp. 277-316.

Honeybee Genome Sequencing Consortium (HGSC) (2006) Insights into social insects from the genome of the honeybee Apis mellifera, Nature 443, 931-949.

Horowitz N.H., Shen S. (1952) Neurospora tyrosinase, J. Biol. Chem. 197, 513-520.

Johnson R.M., Evans J.D., Robinson G.E., Berenbaum M.R. (2009) Changes in transcript abundance relating to colony collapse disorder in honey bees (Apis mellifera), PNAS 106, 14790-14795.
Kopacek P., Weise C., Gotz P. (1995) The prophenoloxidase from the wax moth Galleria mellonella: purification and characterization of the proenzyme, Insect Biochem. Mol. Biol. 25, 10811091.

Korner P., Schmid-Hempel P. (2004) In vivo dynamics of an immune response in the bumble bee Bombus terrestris, J. Invertebr. Pathol. 87, 59-66.

Laughton, A.M. (2008) The ontogeny of immunity in the honey bee, Apis mellifera L. Ph.D. thesis, Department of Animal and Plant Sciences, University of Sheffield, UK.

Leclerc V., Pelte N., El Chamy L., Martinelli C., Ligoxygakis P., Hoffman J. A., Reichhart J. (2006) Prophenoloxidase activation is not required for survival to microbial infections in Drosophila, EMBO Reports 7, 231-235.

Lourenço A.P., Zufelato M.S., Bitondi M.M.G., Simöes Z.L.P. (2005) Molecular characterization of a cDNA encoding prophenoloxidase and its expression in Apis mellifera, Insect Biochem. Mol. Biol. 35, 541-552.

Mason H.S. (1955) Comparative biochemistry of the phenolase complex, Adv. Enzymol. 16, 105-184.

Moret Y., Siva-Jothy M.T. (2003) Adaptive innate immunity? Responsive-mode prophylaxis in the mealworm beetle, Tenebrio molitor, Proc. R. Soc. Lond. B 270, 2475-2480.

Mucklow P.T., Vizoso D.B., Jensen K.H., Refardt D., Ebert D. (2004) Variation in phenoloxidase activity and its relation to parasite resistance within and between populations of Daphnia magna, Proc. R. Soc. Lond. B 271, 1175-1183.

Muhlia-Almazán A., Sánchez-Paz A., García-Carreño F.L. (2008) Invertebrate trypsins: a review, J. Comp. Physiol. B 178, 655-672

Mullen L.M., Goldsworthy G.J. (2006) Immune responses of locusts to challenge with the pathogenic fungus Metarhizium or high doses of laminarin, J. Insect Physiol. 52, 389-398.

Nappi A.J., Vass E., Frey F., Carton Y. (1995) Superoxide anion generation in Drosophila during melanic encapsulation of parasites, Eur. J. Cell Biol. 68, 450-456.

Nappi A.J., Vass E., Malagoli D., Carton Y. (2004) The effects of parasite-derived immune-suppressive factors on the cellular innate immune and autoimmune responses of Drosophila melanogaster, J. Parasitol. 90, 1139-1149.

Nigam Y., Maudlin I., Welburn S., Ratcliffe N.A. (1997) Detection of phenoloxidase activity in the hemolymph of tsetse flies, refractory and susceptible to infection with Trypanosoma brucei rhodesiense, J. Invertebr. Pathol. 69, 279-281.

Oldroyd B.P. (2007) What's killing American honey bees? PloS Biol. 5, e168. 
Ratcliffe N.A., Leonard C., Rowley A.F. (1984) Prophenoloxidase activation: nonself recognition and cell cooperation in insect immunity, Science 226, 557-559.

Riley P.A. (1988) Radicals in melanin biochemistry, Ann. N. Y. Acad. Sci. 551, 111-120.

Saul S.J., Sugumaran M. (1988) Prophenoloxidase activation in the hemolymph of Sarcophaga bullata larvae, Arch. Insect Biochem. Physiol. 7, 91-103.

Schmid M.R., Brockmann A., Pirk C.W.W., Stanley D.W., Tautz J. (2008) Adult honeybees (Apis mellifera L.) abandon hemocytic, but not phenoloxidase-based immunity, J. Insect Physiol. $54,439-444$.

Schmid-Hempel P. (2005) Evolutionary ecology of insect immune defenses, Annu. Rev. Entomol. 50, 529-551.

Schwarzenbach G.A., Ward P.I. (2007) Phenoloxidase activity and pathogen resistance in yellow dung flies Scathophaga stercoraria, J. Evol. Biol. 20, 2192-2199.

Sinsabaugh R.L., Repert D., Weiland T., Golladay S. W., Linkins A.E. (1991) Exoenzyme accumulation in epilithic biofilms, Hydrobiologia 222, 29-37.
Siva-Jothy M.T., Moret Y., Rolff J. (2005) Insect immunity: an evolutionary ecology perspective, Adv. Insect Physiol. 32, 1-48.

Söderhäll K., Cerenius L. (1998) Role of the prophenoloxidase-activating system in invertebrate immunity, Curr. Opin. Immunol. 10, 23-28.

Sugumaran M. (2002) Comparative biochemistry of eumelanogenesis and the protective roles of phenoloxidase and melanin in insects, Pigm. Cell Res. 15, 2-9.

The Merck Index: an encyclopedia of chemicals, drugs, and biologicals (2006) in: O'Neil M.J. (Ed.), Merck, Whitehouse Station, N.J.

Thompson J.J.W. (2002) Aspects of melanin production and immunity in the mealworm beetle Tenebrio molitor, MPhil thesis, Department of Animal and Plant Sciences, University of Sheffield, UK.

Wilson K., Cotter S.C., Reeson A.F., Pell J.K. (2001) Melanism and disease resistance in insects, Ecol. Lett. 4, 637-649.

Wilson-Rich N., Dres S.T., Starks P.T. (2008) The ontogeny of immunity: development of innate immune strength in the honey bee (Apis mellifera), J. Insect Physiol. 54, 1392-1399. 